ROCZNIK

TEOLOGII

KATOLICKIEJ

Tom VII

Rok 2008

\author{
Ks. Michat Sopoćko
}

\title{
ŻYCIE RELIGIJNE W METROPOLII WILEŃSKIEJ 1939-1945 (przygotował do druku ks. Tadeusz Krahel)
}

\section{Wprowadzenie}

W archiwum Sługi Bożego ks. Michała Sopoćki znajduje się w maszynopisie jego opracowanie pt. Życie religijne w Metropolii Wileńskiej 1939-1945 (stron 15). Nie było dotąd drukowane. Ma ono swoją wartość i jest ciekawym przyczynkiem do dziejów Archidiecezji Wileńskiej w latach drugiej wojny światowej. Dlatego decydujemy się na jego publikację.

Zachowany maszynopis jest kopią, ale z własnoręcznym podpisem ks. Michała Sopoćki jako autora. Trudno jest dziś powiedzieć, dokąd trafił oryginał i jakie były okoliczności oraz czas powstania tego tekstu.

Gdy ks. Sopoćko wrócił z Wilna do kraju, szybko udał się z Białegostoku do Warszawy. Złożył wizytę księdzu Prymasowi Kard. Augustowi Hlondowi, który wręczył mu wydaną przez siebie książkę ks. Sopoćki De Misericordia Dei deque ejusdem festo instituendo (Varsaviae 1947) z dedykacją "Czcigodnemu Autorowi życzliwy wydawca - 23 VIII 1947 r." W swoich wspomnieniach ks. Michał napisał też: „Eminencja był dla mnie bardzo życzliwy i polecił napisać sprawozdanie z pobytu w czasie wojny na Wileńszczyźnie, co uczyniłem nieco później”'. Może właśnie życzenie kard. Hlonda było inspiracją do napisania tego tekstu. Trudno jednak jednoznacznie odpowiedzieć twierdząco.

Opracowanie to $\mathrm{w}$ dużym stopniu jest relacją uczestnika zdarzeń okresu drugiej wojny światowej $\mathrm{w}$ Wilnie. W wielu opisanych $\mathrm{w}$ nim wydarzeniach ks. Sopoćko uczestniczył osobiście, o wielu słyszał z ust innych osób. Zwracają tu uwagę sprawy związane z kultem Miłosierdzia Bożego, z budową kościoła Miłosierdzia Bożego na Snipiszkach w Wilnie, ratowaniem Żydów, czy duszpa-

1 M. Sopoćko, Wspomnienia z przeszłości, „Wiadomości Kościelne Archidiecezji w Białymstoku”, 12(1986) nr 1, s. 110-111; Zob. też: H. Ciereszko, Życie i działalność księdza Michała Sopoćki (1888-1975). Pełna biografia Apostoła Miłosierdzia Bożego, Kraków 2006, s. 411. 
sterstwem w kościele Świętej Trójcy. W to wszystko ks. Sopoćko był osobiście zaangażowany, ale pisze tu bez wskazywania na swoją osobę.

Życie religijne w Metropolii Wileńskiej 1939-1945 jest uporządkowanym spojrzeniem chronologicznym na życie religijne w Archidiecezji Wileńskiej, do innych diecezji Metropolii Wileńskiej (pińskiej i łomżyńskiej) mamy tylko pewne odniesienia. Nie jest to opracowanie ściśle naukowe. Spojrzenie, jakie daje na przedstawioną $w$ tytule problematykę, oparte jest na autopsji oraz wiadomościach od osób trzecich. Jedynie stan diecezji przed wojną przedstawia na podstawie danych zawartych w wydawnictwie Kurii Arcybiskupiej Catalogus ecclesiarum et cleri Archidioecesis Vilnensis pro Anno Domini 1939 (Vilnae 1939).

W publikowanym tekście znajdujemy pewne niedokładności i pomyłki, które korygujemy w przypisach. Dziś bowiem, po wielu latach od powstania tego opracowania, badania nad Archidiecezją Wileńską w czasie drugiej wojny światowej posunęły się naprzód i mamy już pełniejszą wiedzę na ten temat.

\section{Życie religijne w Metropolii Wileńskiej 1939-1945}

Metropolia Wileńska obejmuje trzy diecezje: oprócz Archidiecezji Wileńskiej należą do niej Diecezje Łomżyńska i Pińska.

Archidiecezja Wileńska podniesiona do tej godności w roku 1925 obejmowała całe województwo wileńskie i część województw nowogródzkiego i białostockiego. Do Diecezji Pińskiej należało całe województwo poleskie oraz część województw białostockiego i nowogródzkiego. Diecezja Łomżyńska znajduje się na terenie województw białostockiego i częściowo warszawskiego.

Pod względem etnograficznym te diecezje różnią się między sobą: Łomżyńską zamieszkują prawie wyłącznie Polacy (z małym wyjątkiem Litwini), Pińską przeważnie Białorusini i częściowo Polacy. W Archidiecezji Wileńskiej przeważa ludność polska pomieszana $\mathrm{z}$ białoruską i litewską.

Życie religijne w tych trzech diecezjach w latach 1939-1945 rozwijało się niejednakowo. O ile w Diecezji Łomżyńskiej, należącej w czasie ostatniej wojny do tzw. Guberni ${ }^{2}$ upodabniało się do życia w Polsce centralnej, o tyle w Archidiecezji Wileńskiej i Diecezji Pińskiej napotykało na większe trudności ze względu na ustosunkowanie się władz okupacyjnych do tych terenów jako do tzw. Zachodniej Białorusi. Ludność wyznania katolickiego, która się podawała za polską, traktowano jako napływową, zasługującą na wysiedlenie albo nawet na wytępienie. Pod tym względem Archidiecezja Wileńska i Diecezja Pińska nie różniły się między sobą. W tym miejscu będzie mowa o życiu religijnym przede

2 Większość terytorium Diecezji Łomżyńskiej w czasie okupacji niemieckiej znajdowała się w Bezirk Białystok, część - w Generalnej Guberni oraz Prusach Wschodnich. 
wszystkim w Archidiecezji Wileńskiej, ale to samo można odnieść i do Diecezji Pińskiej. O Diecezji Łomżyńskiej ograniczymy się tylko do wzmianki.

Według katalogu kościołów i kleru z roku $1939^{3}$ Archidiecezja liczyła 1485484 wiernych, zgrupowanych w 378 parafiach i 30 dekanatach, obsługiwanych przez 549 kapłanów archidiecezjalnych, 70 - z innych diecezji i 114 zakonników z różnych zgromadzeń zakonnych obrządku łacińskiego. Nadto na tym terenie pracowało 13 kapłanów obrządku wschodniego w 8 punktach duszpasterskich oraz 16 kapelanów wojskowych, obsługujących 8 parafii wojskowych i Korpus Pogranicza. Oprócz kościołów parafialnych w Archidiecezji było 87 punktów duszpasterskich z kościołami lub kaplicami publicznymi obrządku łacińskiego, obsługiwanymi przez wymienionych kapłanów. Oprócz tego było zatrudnionych 385 zakonnic z różnych zgromadzeń czynnych i 48 mniszek klauzurowych, prowadzących życie bogomyślne (benedyktynki, wizytki, dominikanki, karmelitanki).

W licznych szkołach na terenie Archidiecezji pracowało 85 etatowych katechetów i przeszło 100 katechetów i katechetek laików. W samym mieście [Wilnie] było 37 świątyń, obsługiwanych przez 67 kapłanów archidiecezjalnych i około 20 zakonnych, pracujących w 16 parafiach nad 120719 wiernymi. Było męskie Gimnazjum Katolickie Księży Jezuitów i żeńskie Gimnazjum Katolickie ss. Nazaretanek. W szkołach prosperowały sodalicje mariańskie męskie i żeńskie, koła misyjne, koła eucharystyczne, prawie w każdej parafii - Katolickie Stowarzyszenie Młodzieży męskie i żeńskie oraz Kongregacje Trzeciego Zakonu. Wreszcie od roku $1921^{4} \mathrm{w}$ Wilnie rozwijał się Uniwersytet Stefana Batorego z Wydziałem Teologicznym, do którego należeli alumni Seminarium Archidiecezjalnego ${ }^{5}$, w którym w roku 1939 było ich 128. Wśród studentów prosperowały różne korporacje, między innymi i organizacje katolickie, jak: Sodalicja Mariańska, Koło Misyjne, Juventus Christiana, Odrodzenie itp.

W dni świąteczne i niedzielne świątynie bywały przepełnione, a pobożność szczególniejsza wiernych ujawniała się w licznych pielgrzymkach pieszych do Ostrej Bramy, do Kalwarii Wileńskiej i Kalwarii w Miadziole oraz do innych miejsc odpustowych, gdzie tłumnie przystępowali do Sakramentów świętych. Podobnież na 40-godzinnych nabożeństwach, jakie kolejno odbywały się we wszystkich parafiach oraz w dni nieustannej adoracji Przenajświętszego Sakramentu i na rekolekcjach wielkanocnych wierni chętnie korzystali z obecności wielu księży, u których się spowiadali i przystępowali do Sakramentu Ołtarza. Częste wizytacje Arcypasterza i Sufragana (co 5 lat) ułatwiały przystępowanie

3 Catalogus ecclesiarum et cleri Archidioecesis Vilnensis pro Anno Domini 1939, Vilnae 1939.

Uniwersytet Wileński został wskrzeszony w $1919 \mathrm{r}$.

Wileńskie Seminarium Archidiecezjalne w 1925 r. zostało włączone do Wydziału Teologicznego Uniwersytetu Stefana Batorego. 
do bierzmowania i wpływały dodatnio na spotęgowanie ducha religijnego u wiernych.

Liczne świątynie w grodzie Giedymina znajdowały się przeważnie w centrum miasta, a w nowych dzielnicach i w ogóle na peryferiach wierni odczuwali brak ich. Toteż jeszcze przed pierwszą wojną światową zaczęto się troszczyć o wzniesienie nowych kościołów. I tak w roku 1913 staraniem ks. prałata K. Lubiańca powstał w dzielnicy Wilcza Łapa kościół Opatrzności Bożej i rozpoczęto budowę kościoła Serca Jezusowego, w roku 1911 na Sołtaniszkach rozpoczęto budować kościół Niepokalanego Poczęcia, w latach 1925-1929 odbudowano kościół garnizonowy św. Ignacego, w roku 1934 rozpoczęto budowę kościoła oo. Redemptorystów na Pośpieszce, a w roku 1938 powstał Komitet budowy kościoła Miłosierdzia Bożego na Snipiszkach. Pod ten ostatni Magistrat m. Wilna darował plac o powierzchni jednego hektara między ulicami Kalwaryjską i Werkowską, urządzono konkurs na projekt kościoła, z którego wybrano projekt prof. inż. Polkowskiego (16 IV 1939) i w lipcu zamierzano już przystąpić do zakładania fundamentów.

Tymczasem z Zachodu nadchodziły coraz groźniejsze wieści. Hitler po aneksji Austrii i Czechosłowacji głośno pobrzękiwał orężem, zawarł układ o nieagresji z Radziecką Rosją i szykował się do uderzenia na Polskę. Biskupi polscy zebrani na konferencji w Warszawie dnia 26 IV 1939 roku otrzymali od Stolicy Apostolskiej wielkie pełnomocnictwa dla duchowieństwa, o których poinformował Arcybiskup Jałbrzykowski na rekolekcjach kapłańskich w lipcu. Wojna wisiała na włosku i groźba jej oddziaływała hamująco na Komitet budowy kościoła Miłosierdzia Bożego. Wreszcie pierwszego września radio doniosło o bombardowaniu miast polskich przez Niemców, a trzeciego tegoż miesiąca bomby zaczęly padać na gród Giedymina.

Wypadki rozwijały się szybko. Radio informowało o ciężkich walkach naszej armii z najeźdźcą, który wszędzie przeważał uzbrojeniem i liczebnością, posuwając się szybko naprzód i zajmując jedno miasto za drugim. Uciekinierów wojennych było coraz więcej. Sygnały o nalotach ryczały prawie bez przerwy. W mieście nie było ani jednego działa przeciwlotniczego i bombowce niemieckie bez przeszkód rzucały kruszące i zapalające bomby, które wzniecały liczne pożary. 15 września została zniszczona radiowa stacja nadawcza w Raszynie i tylko z zagranicznych stacji dowiadywaliśmy się o tragicznym położeniu kraju i bohatersko broniącej się Warszawie. Wreszcie 17 września nastąpiło uderzenie z drugiej strony: wojska radzieckie przekroczyły granicę i bez przeszkód posuwały się naprzód, 19 września były już w Wilnie, które się poddało bez wystrzału. Wkrótce doszły wieści o kapitulacji Warszawy i cały kraj znalazł się pod okupacją niemiecką i radziecką. 
Archidiecezja Wileńska i Diecezja Pińska znalazły się pod okupacją radziecką, a Łomżyńska - niemiecką ${ }^{6}$. Wraz za wojskiem przybyła przygotowana zawczasu administracja kraju, która zwerbowała miejscowych aktywistów komunistycznych i przy ich pomocy zaczęto sporządzać spisy ludności, segregując ją na tak zwanych miejscowych i przybyłych oraz uciekinierów wojennych. Więzienia zaczęły się przepełniać aresztowanymi, dla których wreszcie zabrakło miejsca i zaczęto tworzyć liczne prowizoryczne ciupy, gdzie było ciasno i duszno do niewytrzymania. W sklepach zabrakło żywności, którą w małej ilości można było otrzymać tylko na kartki. Na ulicach tworzyły się długie ogonki oczekujących na otrzymanie nikłych porcji.

W październiku Stalin odstąpił Wilno z okolicami Litwinom, którzy 28 X 1939 roku uroczyście wkroczyli do grodu Giedymina i zajęli trzy powiaty - wileński, trocki i święciański, jednak wojsko radzieckie pozostało w koszarach na tych obszarach.

Życie religijne w części Archidiecezji zajętej przez Litwinów na razie cieszyło się względną swobodą, ale powoli Polacy zaczęli doznawać ucisku: nakazano rozwiązywać organizacje młodzieży, utrudniać pracę duszpasterską, aresztowano niektórych księży i wywieziono na Litwę $e^{7}$ część gmachu seminaryjnego zabrano na urzędy, chociaż w pozostałej części od ulicy Mostowej tolerowano wykłady, a nawet rząd litewski przez parę miesięcy wypłacał pensję w walucie litewskiej profesorom Wydziału Teologicznego Uniwersytetu Stefana Batorego oraz tolerował w parafiach zbieranie ofiar w naturze na utrzymanie alumnów. Profesorowie $\mathrm{w}$ dni świąteczne i niedzielne wyjeżdżali na prowincję w celu zebrania tych ofiar.

Po paru miesiącach ukazał się dekret likwidujący wszystkie placówki dobroczynne polskie, prowadzone przez zakonnice narodowości polskiej. Z Litwy przybywały Litwinki i obejmowały pracę po Polkach, które po prostu wyrzucano na bruk. To samo dotyczyło warsztatów prowadzonych przez męskie zgromadzenia ukryte.

W połowie lutego 1940 roku zmarł JE bp Kazimierz Michalkiewicz, sufragan wileński, a na jego miejsce przybył JE Arcybiskup Reinys z Litwy. Był to kapłan Archidiecezji Wileńskiej, który w roku 1920 przeniósł się na Litwę ${ }^{8}$, gdzie przez czas jakiś był ministrem spraw zagranicznych. Odsetek Litwinów był nikły, zaledwie $2 \%$ w mieście i jeszcze mniejszy na prowincji ${ }^{9}$. Mieli oni swój kościół

6 W 1939 r. Łomża i większa część terenu diecezji znalazły się pod okupacją sowiecką.

7 Miejscem internowania tych księży był Liszków nad Niemnem.

8 Ksiądz Mieczysław Reinys urodził się w 1884 r., święcenia kapłańskie przyjął w 1907, a biskupem został w 1926. Przed nominacją na biskupa pomocniczego do Wilna, ale w randze arcybiskupa tytularnego, był biskupem koadiutorem w Wiłkowyszkach (Vilkaviskis). W $1922 \mathrm{r}$. władze polskie wydaliły go z Polski na Litwę.

9 W 1938 r. w Archidiecezji Wileńskiej było ok. 90000 wiernych narodowości litewskiej. (A. Szot, Abp Romuald Jałbrzykowski metropolita wileński, Lublin 2002, s. 53-54). 
św. Mikołaja i tworzyli eksterytorialną parafię ${ }^{10}$. Księża Litwini pracowali w parafiach polskich, obsługując rodaków w ich ojczystym języku. Między jednymi i drugimi nie było nieporozumień. Dopiero po zajęciu Wilna przez Litwinów i uruchomieniu pociągów Wilno - Kowno, do nowej stolicy zaczęły przybywać elementy wrogie polskości i wywoływać na tle językowym zajścia, a nawet bójki w kościołach. Tak na przykład w kościele św. Kazimierza, obsługiwanym przez oo. jezuitów, w czasie nabożeństwa majowego w języku polskim Litwini zaczęli śpiewać pieśni narodowe litewskie. Powstało w kościele zamieszanie, a wreszcie bójka między Polakami a Litwinami. Bawiący w Wilnie audytor Nuncjatury Apostolskiej w Kownie, ks. Peroni ${ }^{11}$ pospieszył do kościoła w celu uspokojenia walczących i został sam poważnie poturbowany, aresztowany i odprowadzony do komisariatu, gdzie dopiero spostrzeżono, kim był aresztowany ${ }^{12}$. Podobne zajścia zdarzały się i w innych świątyniach, a szczególnie znamienne miało miejsce w katedrze św. Stanisława na uroczystość Wniebowstąpienia Pańskiego 2 maja, gdy w czasie nieszporów Litwini zaśpiewali swój hymn narodowy, zmuszając kler do wstania.

Znacznie gorzej było pod względem religijnym na tak zwanej Białorusi. Już przy wkroczeniu wojsk radzieckich w roku 1939 maruderzy zamordowali kilku księży ${ }^{13}$. Tak zginął ks. Antoni Twarowski, proboszcz w Juraciszkach, który we wrześniu został zmobilizowany do wojska polskiego jako kapelan i po klęsce powracał do siebie. W podobny sposób życie zakończył ks. Leon Kacperek, zmobilizowany katecheta $\mathrm{z}$ Lidy $^{14}$ oraz ks. Bronisław Fedorowicz, proboszcz w Skrundziach i ks. Bolesław Korń, proboszcz w Mikielewszczyźnie ${ }^{15}$. Nowo wyświęconych kapłanów - ks. Stanisława Zubkowicza ${ }^{16}$ i ks. Stefana Śniegockiego ${ }^{17}$ rozstrzelały wkraczające oddziały radzieckie, na drodze, bez żadnego powodu.

Na kościoły nałożono wielkie podatki, nieopłacenie których groziło zamknięciem. $Z$ początku ludność opłacała je w miarę możności, a gdy zasoby się wyczerpały, dużo świątyń zamknięto lub zamieniono na gmachy użyteczności publicznej (magazyny zbożowe, stajnie dla koni itp.). Zabroniono księżom obsługiwać młodzież do lat 18 , a niestosujących się do tego rozporządzenia

10 Parafia litewska św. Mikołaja w Wilnie liczyła w 1938 r. 1643 wiernych.

11 Ksiądz Vitus Peroni, sekretarz (attaché) Nuncjatury Apostolskiej na Litwie.

12 Te przygody i cały pobyt ks. Peroniego 5-6 V 1940 r. w Wilnie najlepiej opisał Andrzej Grabia Jałbrzykowski (Wspomnienia wileńskie, Warszawa 2005, s. 117-128), który towarzyszył ks. Peroniemu. Ksiądz Peroni nie szedł uspokajać, lecz tylko zobaczyć.

13 Trzech księży (Jana Kryńskiego w Zelwie, Bronisława Fedorowicza w Skrundziach i Antoniego Twarowskiego w Juraciszkach), kleryka oraz paru duchownych prawosławnych zamordowała skomunizowana miejscowa ludność białoruska.

14 Zginął na froncie pod Głowaczowem koło Kozienic.

15 Ksiądz B. Korń został zastrzelony przez żołnierzy sowieckich.

16 Zginął 24 VI $1941 \mathrm{r}$. w Trabach, postrzelony śmiertelnie przez żołnierzy sowieckich.

17 Został rozstrzelany przez Niemców 10 III 1943 r. w Lidzie. 
aresztowano lub przynajmniej zakazano odprawiać przez jakiś czas nabożeństwa w kościele. Kilku młodych księży katechetów za wpływ na młodzież aresztowano i dotychczas nie wiadomo o ich losie (np. ks. Stanisław Matyszczyk, wikary w Widzach) ${ }^{18}$.

Aresztowania wśród ludności były na porządku dziennym. Odbywały się one $\mathrm{w}$ ten sposób, że funkcjonariusze Urzędu Bezpieczeństwa wkraczali do upatrzonych z góry mieszkań i zatrzymywali wszystkich tam wchodzących, nie wypuszczając nikogo, a następnie odprowadzano ich do więzienia, pozostawiając mieszkanie na pastwę losu. W dni świąteczne i niedzielne urządzano łapankę wśród wychodzących z kościoła i aresztowanych odprowadzano wprost do więzienia.

W takich warunkach życie religijne siłą rzeczy zostało zewnętrznie sparaliżowane, ale wewnętrznie coraz bardziej się potęgowało. Wierni zaczęli uświadamiać sobie, że jedyna nadzieja dla nich pozostała w Bogu i Jego nieskończonym Miłosierdziu, do którego tłumnie się garnęli. Obraz Najmiłosierniejszego Zbawiciela w kościele św. Michała był zawsze oblegany przez modlących się, którzy tu doznawali licznych łask - nieraz prawie cudownych, czego dowodem były liczne wota przy obrazie. Fotokopie tego obrazu wkrótce rozpowszechniły się po całej Archidiecezji, po całym kraju, a wreszcie po całym świecie. Nowenna, koronka i litania do Miłosierdzia Bożego, wydane w Krakowie za aprobatą kościelną w roku 1937, uzyskały Imprimatur Kurii Wileńskiej i znalazły się u wiernych w kraju, w oflagach i obozach koncentracyjnych na dalekim Wschodzie i Zachodzie. Odmawiano je wspólnie w więzieniach, schronach i piwnicach, pod gradem spadających bomb i granatów.

$\mathrm{Na}$ odpustach i 40-godzinnych nabożeństwach liczniej niż zwykle gromadzili się wierni i przystępowali do Sakramentów świętych, a księża po pracy $\mathrm{w}$ konfesjonale $\mathrm{w}$ godzinach porannych odprawiali rekolekcje w godzinach poobiednich, albowiem to była jedyna okazja do odprawiania wspólnych ćwiczeń duchownych. Póki można było, urządzano wspaniałe procesje na zakończenie nabożeństwa, które podnosiły wiernych na duchu mimo niebezpieczeństw czyhających na każdym kroku. Wobec braku koni, które były już kilkakrotnie rekwirowane, i innych środków lokomocji, księża przybywali na odpusty przeważnie pieszo lub młodsi na rowerach, zanim nie zaczęły kursować autobusy.

W nocy z 9 na 10 lutego 1940 roku nagle podjechały ciężarówki z funkcjonariuszami Urzędu Bezpieczeństwa ${ }^{19}$ do domów osiedleńców wojskowych i cywilnych, którym kazano w ciągu paru godzin spakować się i udać $\mathrm{w}$ daleką podróż do Kazachstanu. Temperatura przekraczała 20 stopni poniżej zera, a nie wszyscy mieli ciepłe ubranie ani też przygotowany na tak długą podróż prowiant.

18 Uwięziono go w czerwcu 1941 r. i wywieziono do więzienia w Wilejce, gdzie w końcu czerwca w czasie ewakuacji najprawdopodobniej rozstrzelano na terenie więziennym.

19 Właściwie funkcjonariusze NKWD (Narodnyj Komissariat Wnutriennych Dieł - Ludowy Komisariat Spraw Wewnętrznych). 
Przynaglani kolbami musieli jednak szybko się zbierać, ładować do ciężarówek i jechać na stacje kolei żelaznej, odległe często o kilkadziesiąt kilometrów. Tam ładowano ich do bydlęcych wagonów (ciepłuszek) słabo ogrzewanych przez wstawione piecyki. Zanim pociągi, wlokące się żółwim tempem, zawiozły ich do miejsca przeznaczenia, sporo ludzi umarło, a trupy zostały wyrzucone po drodze bez pochówku. Przybyli do Kazachstanu zostali przyjęci wrogo przez ludność miejscową. Niektórzy duszpasterze dobrowolnie pojechali z nieszczęśliwymi, by nieść im posługę duchową (ks. Fiedorowicz) ${ }^{20}$.

W kwietniu 1940 roku po zajęciu przez Hitlera Norwegii w podobny sposób zostali wywiezieni wszyscy urzędnicy służby leśnej, urzędnicy ze służby bezpieczeństwa i administracji, nauczyciele, zamożniejsi gospodarze (kułacy) oraz uciekinierzy wojenni. Wyjazd ich był również nagły, w bydlęcych wagonach, tysiące kilometrów w warunkach ubliżających godności ludzkiej. Wielu z nich umarło po drodze od chłodu, głodu i chorób, szerzących się w takich niehigienicznych warunkach. Rodziny często zostały rozłączone, albowiem mężów skierowano $\mathrm{w}$ jednym kierunku, a żony nieraz $\mathrm{w}$ przeciwnym, dzieci zaś bez opieki chorowały i umierały, zanim dowieziono je do jakichś przytułków czy ochron. Wśród pozostałych, po wywiezieniu sąsiadów, zapanowała panika, przygnębienie i beznadziejność oraz obawa przed podobnym losem. W tych warunkach tylko ufność w Miłosierdzie Boże ratowała od rozpaczy.

14 czerwca 1940 roku radziecki minister spraw zewnętrznych - Mołotow - przez radio ostro zaatakował Litwinów, którzy ponoć nie dotrzymali przyrzeczeń i w kilku wypadkach ustosunkowali się wrogo przeciw wojskom radzieckim. Na Litwie powstała panika. Prezydent Smetona i niektórzy wyżsi urzędnicy zdołali uciec za granicę, a innych tegoż dnia aresztowano, w dniu zaś następnym załadowano do bydlęcych wagonów i wywieziono do Kazachstanu w podobny sposób jak na Białorusi. Razem $\mathrm{z}$ Litwinami wywieziono wówczas dużo Polaków - przeważnie uciekinierów wojennych i internowanych po kampanii wrześniowej wojskowych, którzy potem znaleźli się w Armii Andersa. Delegat Rządu Litewskiego w Wilnie, Bizauskas, żegnając się przed wyjazdem ze znajomymi, powiedział: „Zawsze twierdziłem, że niepodległa Litwa będzie istnieć tylko, dopóki istnieje Polska”.

Stalin skasował ustrój kapitalistyczny Litwy i stworzył przy pomocy miejscowych komunistów Litwę komunistyczną, która rzekomo dobrowolnie prosiła o wcielenie jej do Związku Socjalistycznych Republik Radzieckich jako piętnastą republikę ze stolicą w Wilnie, które odtąd ma się nazywać Vilnius! W tym celu 14 lipca urządzono wybory do Sejmu Litewskiego, który 21 tegoż miesiąca uchwalił wcielenie Litwy do Związku Republik Sowieckich. Ostateczne przyłączenie nastąpiło dopiero 3 sierpnia, a 9 tegoż miesiąca wprowadzono czas

20 Zapewne chodzi o ks. Tadeusza Fedorowicza z Archidiecezji Lwowskiej. 
moskiewski, o 2 godziny wcześniejszy od czasu średnioeuropejskiego. Odtąd życie religijne na Litwie upodobniło się do takiegoż na Białorusi.

Wszędzie kościoły zostały obłożone podatkami, które w Wilnie, słynącym z wielkich kościołów, wynosiły bajońskie sumy i były z góry niewypłacalne. Wkrótce też świątynie większe zostały zamknięte. Obłożono wielkimi podatkami mieszkania księży i trzeba było do większych mieszkań brać sublokatorów. Obsługa wiernych w domach prywatnych została surowo zakazana. Po wsiach grasowali maruderzy, którzy rabowali ludność, szczególnie napadali na plebanie w celach rabunkowych i czasami zabijali bezbronnych. Usunięto religię ze szkół, a nauczania jej po domach prywatnych surowo zakazano.

Wykłady w Seminarium Duchownym rozpoczęły się normalnie we wrześniu, ale warunki pracy były o wiele trudniejsze ze względu na szczupłość lokalu, gdyż - jak już się rzekło - część gmachu seminaryjnego zajmowały sądowe urzędy litewskie. Szczególne trudności powstały, gdy Litwini zajęli mieszkania księży profesorów, którzy musieli się przenieść do cel alumnów. Seminarium utrzymywało się z ofiar wiernych i przetrwało do 22 czerwca 1941 roku.

14 czerwca 1941 roku na terenach Archidiecezji Wileńskiej i Diecezji Pińskiej w godzinach porannych podjechały ciężarówki z funkcjonariuszami Urzędu Bezpieczeństwa do mieszkań uprzednio upatrzonych, z których wyprowadzono aresztowanych mieszkańców, by ich odwieźć do stacji kolei żelaznej. Tam już stały przygotowane długie pociągi, do których ładowano przywiezionych. Za kilka dni pociągi te skierowano na Wschód do Workuty, na Syberię i do Kazachstanu.

Tymczasem 22 czerwca 1941 roku wybuchła wojna niemiecko-radziecka. O godzinie 11 niemieckie bombowce zniszczyły lotnisko w Porubanku pod Wilnem, a w parę godzin później - ukazały się nad miastem, zrzucając na nie bomby zapalające i kruszące. Wówczas został zburzony kościół św. Rafała, pod gruzami którego znalazło śmierć dużo ludzi, chroniących się w podziemiach, a między innymi ks. Wacław Siekierko. Przy kościele św. Katarzyny został raniony ks. Piotr - benedyktyn ${ }^{21}$, który po paru dniach zmarł. Bomby padały przeważnie w pobliżu kościołów i na stacjach kolejowych, gdzie jeszcze stały przygotowane do odjazdu pociągi $z$ aresztowanymi. Powstała panika wśród eskortujących żołnierzy, którzy się porozbiegali, aresztowani zaś pouciekali, unikając wywiezienia, chociaż wielu zostało zabitych lub rannych. Niemieckie bombowce dosięgły pociągi będące już w drodze, gdzie również wywołały panikę i spowodowały śmierć wielu ludzi.

Wkroczenie Niemców ludność przyjęła na razie z pewną ulgą. Ze strony Litwinów były nawet próby wspomagania przybyłych przez ostrzeliwanie z miejsc ukrytych cofających się "bojców” radzieckich. Atoli wkrótce wszystkim dało się we znaki wszechwładne Gestapo, działające bardziej bezwzględnie i sprawniej

${ }^{21}$ Ojciec Piotr Nowacki. 
niż funkcjonariusze bezpieczeństwa radzieckiego. Rozpoczęły się aresztowania i łapanki młodzieży na ulicach, a nawet doraźne rozstrzeliwanie podejrzanych o przynależność do komunistycznych organizacji. Wojska niemieckie posuwały się szybko naprzód, łamiąc po drodze najmniejszy opór, paląc spotkane wsie i miasteczka, a nawet kościoły oraz mordując podejrzanych o nieprzychylność. $\mathrm{W}$ ten sposób zginął ks. Kazimierz Pietkiewicz ${ }^{22}$ w Połukni, ks. Stanisław Staszelis w Surwiliszkach i wielu innych. Przy wkroczeniu Niemców i ucieczce wojsk radzieckich zginęło w Archidiecezji około 30 kapłanów zamordowanych już to przez Niemców, już to przez cofające się oddziały radzieckie ${ }^{23}$.

Nowi okupanci przyszli z gotowym planem politycznym, zmierzającym do wytępienia polskości i katolicyzmu na zajętych terenach. Dlatego z całą bezwzględnością zaczęli niszczyć ślady kultury polskiej w architekturze i w ogóle sztuce i religii. Nie tylko zdzierali godła państwowe, jeżeli gdzieś jeszcze one zostały, ale unicestwiali je nawet $\mathrm{w}$ świątyniach i na grobowcach.

Po zajęciu przez Niemców Mińszczyzny katolicy z tamtych terenów, pozbawieni przez szereg lat pociechy duchowej, zaczęli tłumnie przybywać do kościołów Archidiecezji dla zaspokojenia potrzeb religijnych: tu się spowiadali, przystępowali do Sakramentu Ołtarza, do Sakramentu Małżeństwa itp. Zapraszali również kapłanów do siebie, do swoich świątyń od dłuższego czasu zamkniętych, a przynajmniej pozbawionych należytej obsługi. JE Arcybiskup Wileński chętnie zezwalał kapłanom udać się w tamte strony na misje. Znalazło się kilkunastu gorliwców chętnych na wyjazd, a wśród nich nawet paru profesorów Seminarium Duchownego, ale wkrótce okazało się, że władze okupacyjne stanowczo sprzeciwiają się temu. Kilku z nich zostało aresztowanych, a nawet paru swą gorliwość przypłaciło życiem.

Między innymi udał się na misję w tamte strony ks. dr Henryk Hlebowicz, profesor apologetyki Uniwersytetu Stefana Batorego. Z wielkim zapałem objeżdżał na Mińszczyznie puste dotychczas kościoły, głosił kazania, administrował Sakramenty święte, rozdawał uzbieraną w kraju literaturę religijną, co szczególnie oburzyło okupantów. Wkrótce został aresztowany i 16 listopada $1941 \mathrm{roku}^{24}$ rozstrzelany w lesie w okolicach Borysowa. Podobnie zginęli od kul: ks. Eugeniusz Kulesza, dyrektor Gimnazjum w Drui, ks. Franciszek Kuksewicz - dziekan miorski w Ulle koło Witebska, ks. Stanisław Eliasz - proboszcz w Idołcie ${ }^{25} \mathrm{i}$ inni, którym zarzucano oficjalnie polonizowanie Białorusinów.

22 Ksiądz Kazimierz Packiewicz.

23 W tym czasie zginęło 14 kapłanów, 10 z rąk sowieckich i 4 z rąk Niemców. Zob. T. Krahel, Los duchowieństwa archidiecezji wileńskiej na przełomie dwóch okupacji, [w:] Początek wojny niemiecko-sowieckiej i losy ludności cywilnej, Warszawa 2003, s. 85-90.

24 Ksiądz H. Hlebowicz zginął 9 XI $1941 \mathrm{r}$.

25 Ci trzej kapłani zostali zamordowani przez sowietów w końcu czerwca 1941 r. Zob. T. Krahel, Doświadczeni zniewoleniem. Duchowni archidiecezji wileńskiej represjonowani w latach okupacji sowieckiej (1939-1941), Białystok 2005. 
Jeden z księży Archidiecezji Wileńskiej białoruskiej narodowości, ks. Wincenty Godlewski, został w marionetkowym rządzie białoruskim ministrem oświaty w Mińsku, a jednak został również rozstrzelany przez Niemców razem z innym Białorusinem, ks. Stanisławem Glakowskim, który udał się do Mińszczyzny w celach duszpasterskich. Wynika stąd, że Niemcy głównie prześladowali Kościół katolicki, a tylko pozornie faworyzowali Białorusinów przeciwstawiając ich Polakom. W ten sposób w roku następnym (1942) zginęło 37 kapłanó ${ }^{26}$ Archidiecezji Wileńskiej, rozstrzelanych już to jako polonizatorzy ludności białoruskiej, już to jako zakładnicy, już to w ogóle jako kapłani nawet narodowości białoruskiej, jak np. ks. Aleksander Augustynowicz - proboszcz w Niecieczy, pow. lidzki.

Wobec wrogiego nastawienia hitlerowskich Niemców do Żydów, ci ostatni zaczęli szczerze czy nieszczerze garnąć się do kilku księży, którzy w Wilnie jeszcze przed wojną zajmowali się ich nawróceniem. W paru domach zamożniejszych lekarzy Żydów zorganizowano coś w rodzaju katechumenatu, gdzie systematycznie prowadzono wykłady w celu przygotowania zgłaszających się do chrztu. W chwili wkroczenia Niemców takich katechumenów było około setki; byli to przeważnie ludzie wykształceni: lekarze, inżynierowie, profesorowie, z którymi pogadanki na tematy religijne nie były trudne. $65 \mathrm{z}$ nich przyjęło chrzest święty, po który zgłosili się nawet z getta, gdzie stali się apostołami wśród rodaków. Niektórym udało się ukryć i przetrwać okupację hitlerowską. Owi księża pomagali im z narażeniem własnego życia, wynajdując im kryjówki, a jeden - ks. Romuald Świrkowski, dyrektor Akcji Katolickiej w Archidiecezji Wileńskiej przez niedyskrecję podopiecznych został aresztowany i razem z nimi rozstrzelany na Ponarach pod Wilnem 5 V 1942 roku.

Do getta wileńskiego spędzono Żydów nie tylko z miasta, ale i z okolicznych miasteczek. Było tam niepomiernie ciasno i duszno oraz brakowało elementarnych warunków do życia. Na dzień wypędzano Żydów do pracy, a wieczorem kontrolowano wracających, by nie przynosili z sobą jakichś zapasów. U bramy wejściowej stało zwykle dwóch oprawców z kijami, którymi okładali każdego wchodzącego i wychodzącego. Zaczęły się szerzyć choroby zakaźne i coraz częstsze były wypadki śmierci.

Na wiosnę 1942 roku zaczęto likwidować getto, a raczej Żydów w nim mieszkających. Już od lutego co dzień wyprowadzano kilkuset nieszczęśliwych i pod eskortą pędzono ich na Góry Ponarskie, gdzie żołnierze litewscy pod kierunkiem Niemców rozstrzeliwali ich nad przygotowanymi zawczasu wielkimi dołami. Zabici, a często na pół żywi, padali do tych dołów, które po wypełnieniu zalewano gaszonym wapnem. Niektórym ze skazańców udało się zmylić czujność strzegących gestapowców i zbiec do pobliskiego lasu, a potem błąkali się i umierali głodową śmiercią. W okolicach Ponar w promieniu kilku

26 Raczej około 20. 
kilometrów, od 1942 do 1944 roku, były słyszane strzały z karabinów maszynowych, pozbawiających życie tysiące synów Izraela.

Wśród ochrzczonych Żydów znalazło się kilku prawdziwych apostołów, którzy w getcie pocieszali rodaków, nauczali ich głównych prawd wiary i idąc z nimi na Ponary, pobudzali do żalu za grzechy oraz nakłaniali do pragnienia chrztu świętego, którego wprawdzie już nie mogli otrzymać z wody, ale z krwi. Na placu przy egzekucji rozgrywały się dantejskie sceny, szczególnie wśród matek z dziećmi, budzące współczucie nawet u na pół pijanych katów. Szczególnie na uwagę zasługuje pewien docent Uniwersytetu Stefana Batorego, dr Juliusz Genzel, który podziękował za propozycję ucieczki, oświadczając, że jego miejsce jest w getcie, by nieść pomoc rodakom - pomoc fizyczną i duchową. Jako lekarz ocalał w szpitalu zakaźnym i po wojnie wyjechał do Australii.

W ostatnią niedzielę Adwentu 1941 roku pod pozorem jakiejś grasującej choroby zamknięto wszystkie kościoły w mieście i na prowincji. Księża mogli wejść tylko przez zakrystie, by po cichu odprawić Mszę Świętą. Wytworzył się nastrój przygnębiający w oczekiwaniu czegoś, co miało nastąpić. W pierwszych dniach stycznia aresztowano ks. Romualda Świrkowskiego, proboszcza parafii Świętego Ducha, który z więzienia powiadomił, że uwięziono go jako przedstawiciela duchowieństwa i radził kilku księżom ukrywać się lub wcale Wilno opuścić, albowiem przy przesłuchaniu wciąż wymieniają ich nazwiska.

3 marca funkcjonariusze Urzędu Bezpieczeństwa okrążyli Seminarium i kazali księżom profesorom i alumnom w ciągu paru godzin spakować się, by odjechać do więzienia na Łukiszkach. Tegoż dnia aresztowano i umieszczono w tymże więzieniu wszystkich księży Polaków. 22 marca przeprowadzono rewizję w Kurii Metropolitalnej i aresztowano JE Arcybiskupa Jałbrzykowskiego $\mathrm{z}$ kanclerzem ks. Adamem Sawickim i odwieziono do klasztoru Księży Marianów w Mariampolu. 23 marca zbombardowano Wilno i zburzono kościół św. Mikołaja z przylegającą do niego plebanią, w której zginął proboszcz parafii litewskiej, ks. Krzysztof Czybir, a JE abp Reinys został ciężko ranny. 26 marca aresztowano i osadzono w więzieniu na Łukiszkach wszystkich zakonników i zakonnice narodowości polskiej.

Święta wielkanocne tego roku Wilno obchodziło w żałobie. Dzwony milczały. Ludność posyłała paczki aresztowanemu duchowieństwu do więzień. W paczkach żywnościowych przesyłano konsekrowane komunikanty, by uwięzieni mogli się posilić chlebem anielskim, który zakonnicom rozdzieliła przełożona ss. urszulanek ${ }^{27}$. Kilku księżom polskim udało się uniknąć aresztowania. Urządzili oni wiernym nowennę do Miłosierdzia Bożego od Wielkiego Piątku do Niedzieli Przewodniej. Na to nabożeństwo przybyły tłumy wiernych, którzy

27 Według relacji s. Stanisławy Kosmowskiej, przełożonej sióstr urszulanek ze Skopówki w Wilnie, do jej więziennej celi na Łukiszkach konsekrowane komunikanty dostarczyła w zawiniątku dozorczyni, Litwinka. 
widzieli ratunek tylko w Miłosierdziu Bożym i w Niedzielę Białą przystąpili do Komunii świętej.

Wkrótce księża Polacy z Wilna zostali w większości zwolnieni, a profesorowie wywiezieni do obozów w Wiłkowyszkach, Prowieniszkach i Szałtupiu, gdzie musieli pracować na roli jako zwykli parobcy. Kierownicy tych upaństwowionych majątków rolnych specjalnie traktowali ich w sposób grubiański, a nad niektórymi wprost się pastwili. Wilnianie zorganizowali pomoc dla nich, dzięki której głodu tam nie było i jakoś wszyscy przetrwali.

30 maja zakonnice zostały $\mathrm{z}$ więzienia zwolnione, $\mathrm{z}$ tym że miały się przebrać po świecku, by wyjechać do Niemiec na roboty lub pracować w upaństwowionych majątkach na Litwie jako zwykłe wyrobnice. Alumni również zostali wywiezieni do Niemiec, a niektórym udało się zbiec z pociągu i dostać do Otwocka, gdzie oo. jezuici zorganizowali dla nich wykłady z teologii i przygotowali ich do święceń. Podobnie paru profesorom udało się uniknąć aresztowania. Ukrywali się oni na wsi. Jako ogrodnicy i rolnicy przetrwali czas okupacji hitlerowskiej ${ }^{28}$.

Życie religijne zarówno w Archidiecezji Wileńskiej jak i Diecezji Pińskiej zewnętrznie prawie zamarło, chociaż wewnętrznie dzięki szerzącemu się kultowi Miłosierdzia Bożego bynajmniej nie osłabło. Wprawdzie kościoły były przeważnie zamknięte, a księża uwięzieni lub w przebraniu ukrywali się po wsiach, ale pulsował duch religijny i wzmagała się ufność w nieskończone Miłosierdzie Boże. Agnuski i medaliki Najmiłosierniejszego Zbawiciela znajdowały się prawie u wszystkich, przedostały się do polskich oddziałów partyzanckich, organizowanych dla ochrony osiedli polskich przed maruderami i spadochroniarzami radzieckimi grasującymi po kraju.

Do walki z okupantem powstały dwie partyzantki kłócące się między sobą - polska i radziecka, składająca się ze spadochroniarzy. Jedna i druga utrzymywały się kosztem ludności miejscowej i bez tego już wycieńczonej. Bardziej bezwzględne były oddziały radzieckie, rabujące wsie i osiedla, a po ich odejściu przybywała zwykle niemiecka ekspedycja karna, mszcząca się za rzekomo dobrowolne wspieranie bolszewików. Wówczas te wsie otaczano wojskiem, mieszkańców wyprowadzano do lasu i co piątego rozstrzeliwano, a budynki puszczano z dymem. Spotkanego kapłana Niemcy uważali za największego wroga i rozstrzeliwali bez sądu. W taki sposób w 1942 roku zginęło w Archidiecezji Wileńskiej 34 kapłanów, w roku 1943 - tyleż, a do połowy roku 1944 jeszcze 22, oprócz tych, którzy zostali wywiezieni do Oświęcimia, Lublina czy Dachau. Łącznie na terenie Wileńszczyzny poniosło śmierć z ręki okupantów

28 Z profesorów Wydziału Teologicznego i Seminarium aresztowania uniknęli: ks. Michał Sopoćko, ks. Ignacy Świrski i ks. Władysław Rusznicki. Ukrywali się do końca okupacji niemieckiej. 
w czasie wojny 142 kapłanów jako odważnych wyznawców wiary, zakładników i obrońców uciśnionej ludności ${ }^{29}$.

Tułaczka po obozach i kryjówkach trwała przeszło 30 miesięcy, aż wreszcie w lipcu 1944 roku jedni okupanci zaczęli się cofać, by dać miejsce okupantom ze Wschodu. Cofające się oddziały niemieckie, wycieńczone i głodne, a mimo to bezustannie walczące $\mathrm{z}$ następującymi hordami wschodnimi, niszczyły po drodze wszystko, paląc wsie i miasteczka. Wilno płonęło przez parę tygodni i zostało zniszczone w $60 \%$. Całe ulice padły wówczas ofiarą Znicza zgodnie z rozkazem Führera, by pozostawić tylko niebo i ziemię. Na domiar złego na Dworcu Wileńskim nastąpiło zderzenie dwóch pociągów $\mathrm{z}$ amunicją, które silnym podmuchem wysadziło $\mathrm{w}$ powietrze znajdujący się w pobliżu kościół św. Stefana i pozbawiło szyb wiele domów i kościołów.

W pierwszych dniach sierpnia wrócił z Mariampola JE Arcybiskup, witany entuzjastycznie przez wiernych. Przywiozło go wojskowe auto radzieckie. Następnie zaczęli się zjawiać księża profesorowie z obozów i kryjówek. Niektórzy z nich zapuścili zarost i trudno było ich rozpoznać. 1 października rozpoczęły się wykłady w Seminarium, które jakoś przetrwało do 20 lutego 1945 roku. Wprawdzie od 1942 do 1944 roku funkcjonowało Seminarium Duchowne Litewskie w murach św. Michalskich, ale prowadziło żywot suchotniczy: przez tych parę lat wydało zaledwie kilku kapłanów.

Nowe władze okupacyjne na razie nie wtrącały się do życia religijnego, które zaczęło płynąć normalnie. Atoli wkrótce rozpoczął się ucisk: wznowiono podatki na kościoły i budynki służące do kultu religijnego, utrudniano udawanie się księży do chorych, zamykano za nieuiszczone opłaty świątynie oraz aresztowano podejrzanych o współpracę z Niemcami niektórych obywateli, a wśród nich i kilku kapłanów. Wreszcie w połowie stycznia 1945 roku nastąpiła rewizja w Kurii Metropolitalnej i aresztowanie JE Arcybiskupa, kanclerza ks. A. Sawickiego i kilku księży. $Z$ chorym Arcybiskupem musiała się udać do więzienia pielęgniarka s. szarytka. Jeden z księży posłał Mu ołtarz polowy, przy którym codziennie odprawiał Mszę Świętą.

20 lutego 1945 roku do Seminarium w czasie wykładu przybyli funkcjonariusze Urzędu Bezpieczeństwa (NKGB) z lejtnantem Pietkiawiczusem na czele, który oświadczył, że Seminarium funkcjonuje nielegalnie i kazał profesorom oraz alumnom je opuścić. Na drugi dzień powrócił z więzienia JE Arcybiskup i po naradzie zadecydował, że trzeba przenieść Seminarium Duchowne do Białegostoku. Jest to miasto wojewódzkie należące do Archidiecezji Wileńskiej,

29 Liczby te są zawyżone. Pomyłka wynikła stąd, że autor oparł się na wykazie Sacerdotes demortui tempore belli 1939 a., dołączonym do Kalendarium liturgicum pro A. D. 1946 ad usum Archidioecesis, Białystok [1945]. W wykazie tym figurują też kapłani, którzy umarli śmiercią naturalną. W czasie drugiej wojny światowej zginęło około 112 kapłanów i kleryków Archidiecezji Wileńskiej oraz kapłanów z innych diecezji i zakonników, pracujących na terenie tej Archidiecezji. 
a ostatnio przynależne do Polskiej Rzeczpospolitej Ludowej. Natychmiast udał się tam wyznaczony zarząd seminaryjny, który po porozumieniu z władzami miejscowymi zorganizował Seminarium w gmachu braciszków pod wezwaniem Zgromadzenia Sług Najświętszej Maryi Panny przy ul. Słonimskiej 8. 1 kwietnia udali się tam księża profesorowie z alumnami, by 1 maja rozpocząć wykłady.

JE Arcybiskup Jałbrzykowski pozostał w Wilnie, ale już w lipcu otrzymał polecenie, by udać się do Białegostoku, dokąd też wkrótce wyjechał. Stan religijności w Archidiecezji był bardzo opłakany. Na Litwie niby funkcjonowały kościoły, ale powoli były pod różnymi pozorami zamykane. W Wilnie z 37 świątyń przed wojną pozostało tylko sześć: Ostrobramski, św. Ducha, św. Piotra, św. Mikołaja, św. Anny, św. Rafała i na przedmieściu Niepokalanego Poczęcia. Katedrę zamieniono na muzeum, św. Kazimierza - na muzeum bezbożnicze, a inne na różne składy i magazyny.

Znacznie gorzej było na tak zwanej Białorusi, gdzie łączono wyznanie katolickie z narodowością polską, którą przede wszystkim zamierzano zniszczyć. Tam pod byle pretekstem zamykano kościoły i tylko w niektórych (w kilku na powiat) pozwalano się modlić po zapłaceniu względnie wysokiego podatku. Sporo księży aresztowano, a innym stawiano do wyboru - dobrowolny wyjazd do Polski Ludowej lub na Wschód do obozów. Młodzieży do 18. roku zabroniono uczęszczać do kościoła pod odpowiedzialnością proboszcza, którego, w razie stwierdzenia, że jednak młodzież do kościoła uczęszcza, pozbawiano prawa spełniania posług duchowych. Przy parafiach potworzono komitety, które wypłacały księżom miesięczne nikłe wynagrodzenie, a opłaty za posługi duszpasterskie przeznaczały na utrzymanie budynku. W takich warunkach większość kapłanów skorzystało $\mathrm{z}$ odchodzących po Jałcie transportów i wolało razem z parafianami wyjechać do Polski Ludowej. W ciągu lat 1945 i 1946 wyjechało ich 145 do różnych diecezji. Transportów odeszło w tym czasie przeszło 125 po 900-1000 osób. Na Białorusi na 370 funkcjonujących przed wojną świątyń, a obsługiwanych przez prawie 600 kapłanów, pozostało na placówkach niespełna 80, po 1-3 na dekanat, a i tym nie pozwalano pracować normalnie. Byli to ludzie przeważnie w wieku sędziwym, którym wyjazd na nowe tereny nie odpowiadał. Na całą Litwę istniało jedno Seminarium Duchowne w Kownie, w którym była ograniczona liczba alumnów, wybranych z różnych diecezji według wskazówek Urzędu Bezpieczeństwa. Z Archidiecezji Wileńskiej było tylko paru alumnów, tak że nie co roku mógł przybyć jeden kapłan.

Na miejsce wysiedlonych Polaków przybywali osiedleńcy z Litwy i przeważnie z Rosji. Wśród tych ostatnich byli Polacy i Litwini wyznania katolickiego, którzy już zapomnieli języka ojczystego, a rozumieli tylko po rosyjsku. Na ich prośbę Kuria Metropolitalna zezwoliła na odprawianie nabożeństw i głoszenie kazań w języku rosyjskim. Wobec tego w kościele Świętej Trójcy przy ul. Dominikańskiej w dni świąteczne i niedzielne odprawiało się nabożeństwo w następującym 
porządku: 1) Msza Święta czytana, w czasie której śpiewano pieśni katolickie w języku rosyjskim, 2) po Mszy Świętej kazania również po rosyjsku, 3) w końcu małe wystawienie Przenajświętszego Sakramentu z odpowiednimi modlitwami i pieśniami po rosyjsku. Frekwencja była dosyć liczna, kościół był przeważnie przepełniony. Zdarzały się nawrócenia, a przynajmniej wieczorem przychodzili rodowici Rosjanie na nikodemowe rozmowy na tematy religijne.

$\mathrm{Na}$ razie władze cywilne nie stawiały przeszkód tej akcji, ale po upływie jakiegoś czasu zaczęły się interesować i - jak potem się okazało - księdza ${ }^{30}$, który ją prowadził zamierzano wywieźć na Wschód, gdyby on na wezwanie Arcybiskupa nie wyjechał do Polski.

Krótki rys życia religijnego w okresie 1939-1945 w Metropolii Wileńskiej dotyczy głównie Archidiecezji Wileńskiej i tylko przez analogię warunków można to odnieść i do Diecezji Pińskiej, z tym zastrzeżeniem, że w tej ostatniej mniejszy odsetek stanowili Polacy, przeciwko którym głównie były wymierzane ataki okupantów. Stamtąd większość obywateli wyjechało do Polski Ludowej, a z nimi i większość księży opuściło swoje placówki. Obecnie w tamtej części Diecezji Pińskiej pozostało tylko 12-15 kapłanów, obsługujących w niezwykle trudnych warunkach całe byłe województwo poleskie oraz część nowogródzkiego i białostockiego.

W Diecezji Łomżyńskiej, gdzie pod względem narodowościowym i religijnym ludność jest jednolita, łatwiej było przetrwać ataki okupantów, a po ich ustąpieniu prędzej zorganizować życie religijne. Jakkolwiek i dziś panują tam stosunki dalekie od normalnych, ale parafie są obsadzone, wszystkie świątynie czynne, a pasterze sprawują rządy bez nadzwyczajnych przeszkód.

30 Chodzi o ks. M. Sopoćkę. 